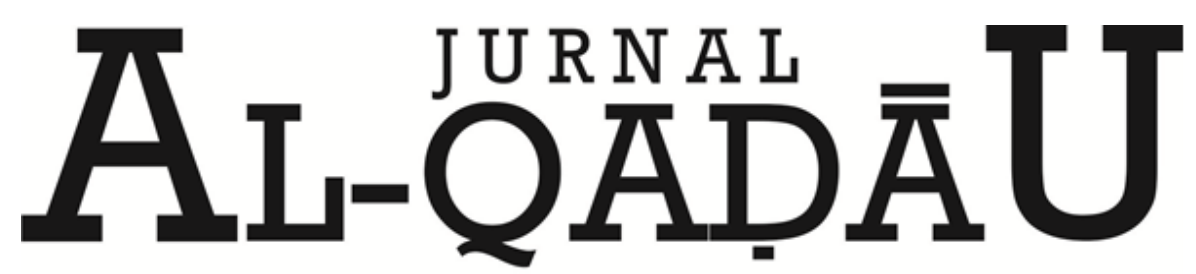

PERADILAN dan HUKUM KELUARGA ISLAM

\title{
Pelaksanaan Hukum Kewarisan Islam di Kota Makassar
}

\section{The Implemention of Islamic Inheritance Law in the City of Makassar}

Muhammad Anis

Dosen Fakultas Syariah dan Hukum UIN Alauddin Makassar

Email: muhammadanis196̄̄gmail.com

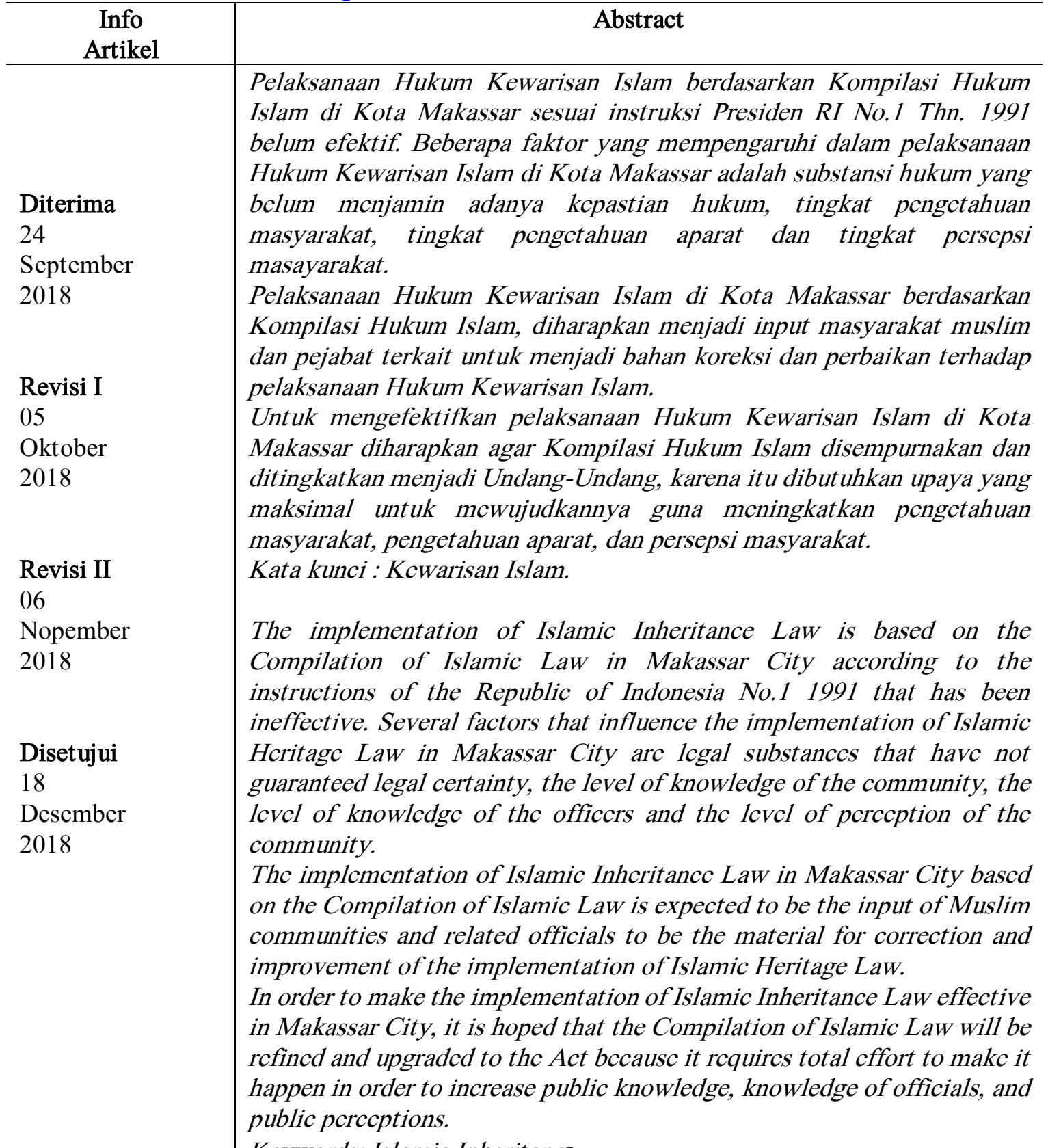

Keywords: Islamic Inheritance. 
Muhammad Anis

\section{A. PENDAHULUAN}

Sejalan dengan laju pertumbuhan dan perkembangan manusia dan peradabannya dewasa ini, maka kebutuhan manusia semakin kompleks yang menyebabkan timbulnya masalah-masalah bagi manusia, baik dalam lingkungan masyarakat maupun dalam lingkungan keluarga itu sendiri. Diantara masalah-masalah yang banyak terjadi akhir-akhir ini adalah masalah kewarisan. Al Qur'an sebagai pedoman hidup bagi ummat islam, di dalamnya berisi kaedah-kaedah atau normanorma yang mengatur segala aspek kehidupan manusia, termasuk hukum kewarisan. Kaedah-kaedah atau norma-norma tersebut tersusun secara sistematis dalam suatu totalitas, sehingga mempunyai hubungan fungsional dalam rangka mengarahkan manusia kepada pembentukan dirinya menjadi manusia yang sempurna.

Manusia sebagai mahluk tuhan mempunyai keimanan terhadap penciptanya yang dikatakan taat manakala ia melaksanakan hukum-hukum yang telah disyariatkan oleh tuhan pencipta alam semesta secara menyeluruh. Untuk itu, kesadaran ummat islam dalam melaksanakan perintah Allah subhanahu wa ta'ala sebagaimana yang telah digariskan dalam Al Qur'an dan Sunnah sebagai manifestasi dan nilai-nilai keimanan seseorang. Sebagaimana dalam Al Qur'an dalam surat An Nisa ayat 65 ;

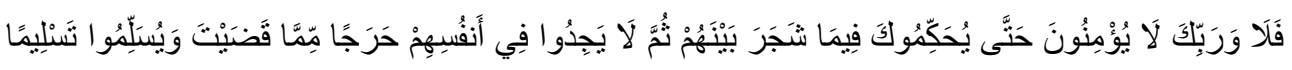

Terjemahan:

"Maka demi Tuhanmu, mereka (pada hakekatnya) tidak beriman hingga mereka menjadikan kamu hakim terhadap perkara yang mereka perselisihkan, kemudian mereka tidak merasa dalam hati mereka sesuatu keberatan terhadap putusan yang kamu berikan, dan mereka menerima dengan sepenuhnya".

Dewasa ini, sistem hukum kewarisan yang berlaku bagi warga negara indonesia masih beragam, sebab selain sistem hukum islam yang berlaku juga masih berlaku sistem hukum adat dan sistem hukum perdata, halmana ketiga sistem hukum tersebut masing-masing mempunyai dasar hukum berlakunya, sebagaimana dikemukakan oleh Idris Ramulyo bahwa :

1. Sistem hukum perdata barat (eropa) yang tercantum dalam kitab undangundang hukum perdata berdasarkan ketentuan pasal 131 IS. Stablad 1917 Nomor 129 jo. Stablad 1917 Nomor 12 tentang penundukan diri terhadap hukum eropa, maka Bergelijk Wetboet(WB) tersebut berlaku bagi :

a. orang-orang eropa dan mereka mempersamakan dengan orang eropa.

b. orang timur asing tionghoa.

c. orang timur asing lainnya dan orang-orang indonesia yang menundukkan diri tehadapaphukum eropa.

2. Sistem Hukum Kewarisan Islam adat yang beraneka ragam pula sistemnya, yang dipengaruhi oleh bentuk etnis diberagai daerah dilingkungan hukum adat.

3. Sistem hukum kewarisan islam yang berlaku bagi orang indonesia yang beragama Islam, berdasarkan Stablad 1855 Nomor 2 di indonesia dengan 
Stablad 1929 nomor 221, yang telah diubah dan sebagainya, terakhir berdasar pasal 29 undang-undang 1945 jo. Ketetapan MPR Nomor II/MPR/1983. ${ }^{1}$

Dengan berlakunya ketiga sistem hukum kewarisan tersebut di Indonesia akibatnya sampai sekarang masih tetap berpengaruh terhadap penyelesaian masalah kewarisan, sebab sampai mereka dapat memilih salah satu dari ketiga sistem hukum tersebut, hal mana sesuai dengan apa yang ditetapkan dalam penjelasan umum undangundang nomor 7 tahun 1989 tentang peradilan agama. Tetapi jika dikaji dengan cermat isi pasal 1(ayat 1) undang-undang nomor 7 tahun 1989 yang membatasi pengertian pengadilan agama, yang menekankan bahwa pengadilan agama adalah pengadilan bagi orang-orang yang beragama Islam.

Dari batasan pengertian peradilan agama tersebut, jelas bahwa dengan berlakunya undang-undang Nomor 7 tahun 1989 tentang peradilan agama yang diundangkan pada tanggal 14 Desember 1989 maka masalah kewarisan bagi ummat Islam merupakan kewenangan bagi pengadilan agama untuk menyelesaikan perkara kewarisan berdasarkan hukum kewarisan Islam. Kemudian yang menjadi acuan pelaksanaan undang-undang nomor 7 tahun 1989 tentang kewarisan ini, telah diatur dalam kompilasi hukum islam dan diemplementasikan berdasarkan instruksi presiden nomor 1 tahun 1991 tanggal 10 Juni 1991.

Masyarakat kota Makassar yang mayoritas penduduknya beragama Islam, mereka senantiasa ditatar untuk konsisten terhadap ajaran agamanya sebagaimana yang telah ditetapkan Al Qur'an, dalam mengatur tata kehidupannya termasuk masalah kewarisan. Dinamika kehidupan masyarakat hendaknya tetap sejalan dengan dinamika yang dikehendaki oleh Allah swt. dan Rasulullah saw. Berdasarkan uraian latar belakang masalah di atas, dipandang perlu mengkonkritkan permasalahan yang akan ditelit, sejauh mana pelaksanaan hukum kewarisan islam di kota Makassar dan faktorfaktor apa yang mempengaruhi pelaksanaan hukum kewarisan islam di kota Makassar.

\section{B. METODE PENELITIAN}

Jenis penelitian yang digunakan adalah penelitian lapangan (field research), lokasi penelitian di wilayah Kota Makassar penelitian ini menggunakan pendekatan empiris normatif dan empiris sosiologi.

Metode pengumpulan data dalam penelitian ini digunakan beberapa teknik pengumpulan data, yaitu: Wawancara, akan diberikan kepada narasumber sebagai salah satu sumber informasi bagi Penulis dalam menjawab rumusan masalah yang ada dengan cara mengajukan pertanyaan-pertanyaan yang erat kaitannya dengan masalah yang diangkat oleh penulis. observasi, penulis mengumpulkan data-data, peraturanperaturan, dan dokumen-dokumen dengan menelaah literatur yang berkaitan dengan masalah kewarisan islam pada instansi terkait.

Instrumen penelitian instrumen penelitian yang dipakai untuk memperoleh data-data penelitian saat sesudah memasuki tahap pengumpulan data di lapangan

${ }^{1}$ Idris Ramulyo, Hukum Kewarisan Islam: Studi Kasus, Perbandingan Ajaran Syafii (Patrilinial), Hazairin (Bilateral) dan Praktek di Pengadilan Agama (Cet. II; Jakarta: Ind Hill. 1987), h. 2. 
seperti wawancara, observasi, Instrumen penelitian ini merujuk pada metodologi penelitian.

Teknik pengolahan dan analisis data, bahwa data yang diperoleh dan dikumpulkan dianalisa secara kuantitatif yaitu suatu cara penelitian yang yang dilakukan guna mencari kebenaran kuantitattif.

\section{PEMBAHASAN}

\section{Pengertian Hukum Kewarisan Islam}

Kewarisan terambil dari bahasa arab yaitu mawaris bentuk jamak dari miraas yang sama dengan intiqaal artinya perpindahan, yang berarti perpindahan sesuatu dari satu orang kepada orang lain baik secara konkrit maupun secara abstrak.

Adapun perpindahan yang konkrit misalnya perpindahan harta benda sedangkan yang abstrak sepertinya perpindahan ilmu pengetahuan sebagaimana sabda Rasulullah saw. :

Artinya:

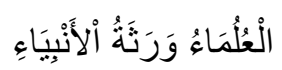

"Ulama adalah pewaris Nabi-nabi".

Dengan demikian apabila kita membahas tentang hukum kewarisan pada umumnya, maka kita akan sampai kepada dua masalah, yang pertama adanya seorang yang meninggal dunia disebut pewaris, meninggalkan kekayaannya sebagai warisan, yang kedua meninggalkan orang-orang yang berhak akan menerima harta peninggalam tersebut, disebut dengan ahli waris. Manusia sebagai insan beragama, sebagai mahluk sosial mempunyai hak-hak dan kewajiban-kewajiban, disamping itu manusia mempunyai kewajiban khusus terhadap anggota keluarganya, istri bersama anakanaknya, demikian pula kewajiban umum terhadap masyarakat dan negara dengan kata lain ada suatu hubungan timbal balik antara seorang individusebagai seorang anggota masyarakat dengan alam sekitarnya, manusia itu suci bagi manusia lainnya, jadi berarti saling membutuhkan sebagaimana dalam Al-Qur'an surat An Nisa' ayat 1 :

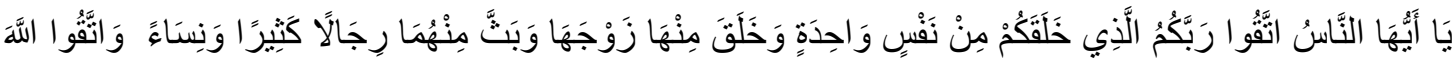

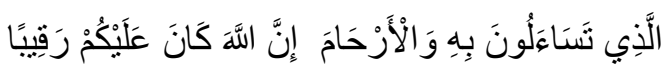

Terjemahan:

"Hai sekalian manusia, bertakwalah kepada Tuhan-mu yang telah menciptakan kamu dari seorang diri, dan dari padanya Allah menciptakan isterinya; dan dari pada keduanya Allah memperkembang biakkan laki-laki dan perempuan yang banyak. Dan bertakwalah kepada Allah yang dengan (mempergunakan) namaNya kamu saling meminta satu sama lain, dan (peliharalah) hubungan silaturrahim. Sesungguhnya Allah selalu menjaga dan mengawasi kamu."

Ketika manusia sebagai individu meninggal dunia, maka akan timbul persoalan, melihat keadaan yang demikian membutuhkan aturan-aturan hukum yang mengatur bagaimana cara mengatasi persoalan yang akan terjadi akibat adanya hubungan hukum yang meninggal dunia dengan keluarga yang ditinggalkan. Kemungkinan, ada 
kewajiban-kewajiban yang harus dipenuhi baik simeninggal dengan yang ditinggal. Dalam hal ini timbul masalah warisan, yaitu harta benda yang ditinggalkan, siapa yang berhak menerima harta peninggalan, kepada siapa ahli waris diserahkan, bagaimana jika ahli waris lebih dari satu orang. Masalah demikian membutuhkan aturan-aturan hukumyang mengatur bagaimana cara menyelesaikan persoalan tersebut.

Menurut Idris Ramulyo, bahwa yang dimaksud dengan warisan ialah harta kekayaan dari seseorang yang telah meninggal dunia, dapat berupa :

1. Harta kekayaan yang berwujud dan dapat dinilai dengan uang serta piutang atau activa.

2. Harta kekayaan yang merupakan hutang-hutang yang belum dibayar pada saat meninggal dunia atau pasiva

3. Harta bersama antara suami-isteri bilamana terjadi syirkah pada saat akad nikah dilaksanakan, harta bersama dapat berupa ;

a. Harta bawaan masing-masing sisuami ataupun si isteri yang diperoleh/dimiliki sebelum akad nikah baik berasal dari warisan, hibah ataupun usaha-usaha mereka masing-masing sendiri.

b. Harta masing-masing suami-isteri yang diperoleh/dimiliki sesudah ijab kabul pernikahan atau selama perkawinan, tetapi bukan diperoleh dari perusahaan bersama, misalnya memperoleh warisan, hibah atau pemberian lain.

c. Harta yang diperoleh sewaktu dalam perkawinan atau usaha mereka berdua atau salah seorang dari mereka.

4. Harta bawaan yang dapat dimiliki langsung oleh kedua belah pihak, misalnya harta pustaka dari kerabat mereka yang dibawa sebagai modal pertama dalam perkawinan yang harus dikembalikan kepada asalnya.

5. Harta warisan yang merupakan harta peninggalan yang dapat dibagi kepada ahli waris ialah harta keseluruhannya sesudah dipisahkan dari harta suamiisteri dan harta pustaka, harta bawaan yang tidak boleh dimiliki, dikurangi hutang-hutang dan wasiat. ${ }^{2}$

Menurut Sudarsono, bahwa hukum kewarisan Islam memiliki beberapa unsur, adapun unsur-unsur warisan/rukun-rukun warisan(arkanaut mirats)adalah sebagai berikut :

1. Muwarrits(orang-orang yang mewariskan), yakni adanya orang yang meninggal dunia atau si pewaris. Hukum ini didalam hukum waris BW disebut erflater.

2. Warist(orang yang berhak mewaris; disebut ahli waris), yakni adanya ahli waris yang ditinggalkan si wali yang masih hidup dan berhak menerima pusaka si pewaris, unsur ini dalam hukum waris BW disebut erfgenam.

3. Mauruts miratsatan tarikah(harta warisan), yakni adanya harta peninggalan(pusaka) si mati yang memang nyata-nyata miliknya. Unsur ini didalam hukum waris BW disebut erfenis. ${ }^{3}$

${ }^{2}$ Idris Ramulyo, Hukum Kewarisan Islam: Studi Kasus, Perbandingan Ajaran Syafii (Patrilinial), Hazairin (Bilateral) dan Praktek di Pengadilan Agama, Indhil, h. 48-49

${ }^{3}$ Sudarsono, Hukum Waris dan Sistem Bilateral (Jakarta: Rineka Cipta,. 1991), h. 98 
Dari pengertian tersebut diatas dapat ditarik kesimpulan bahwa mengenai harta warisan atau harta peninggalan baik dalam hukum adat maupun hukum Islam mempunyai persamaan dan terdapat hubungan yang erat satu sama lain, bahwa yang dimaksud harta peninggalan yang boleh dibagi -bagikan secara individu kepada ahli waris ialah harta peninggalan yang sudah dibersihkan dari unsur-unsur harta pribadi yang dibawah sebelum perkawinan maupun sesudahnya, maka dengan demikian dapatlah kita mengambil suatu kesimpulan bahwa hukum kewarisan Islam adalah suatu ketentuan yang mengatur pembagian harta yang telah ditentukan dan wajib dilaksanakan yang didalamnya memuat tiga unsur, yaitu :

1. Ada orang yang meninggal (pewaris)

2. Ada harta yang ditinggalkan (tirkah)

3. Ada ahli waris.

Adapun pengertian huk um kewarisan Islam menurut para sarjana antara lain:

1. Menurut Idris Ramulyo (1987:49) bahwa hukum kewarisan himpunan hukum yang mengatur tentang siapa ahli waris yang berhak mewarisi harta peninggalan seorang yang meninggal yang meninggalkan harta peninggalan, bagaimana kedudukan masing-masing ahli waris secara adil dan sempurna. ${ }^{4}$

2. Menurut Wiryono Projodikora (1966:27) menyatakan bahwa hukum waris adalah hukum-hukum atau peraturan-peraturan yang mengatur tentang apakah dan bagaimanakah berbagai hak-hak dan kewajiban tentang kekayaan seorang pada waktu ia meninggal dunia akan beralih kepada orang lain yang masih hidup. ${ }^{5}$

3. Menurut Idris Jakfar (1995: 4) merumuskan pengertian hukum kewarisan Islam, sebagai berikut: seperangkat aturan-aturan hukum tentang pemindahan hak pemilikan harta peninggalan pewaris, mengatur kedudukan ahli waris yang berhak dan berapa bagiannya masing-masing secara adil dan sempurna sesuai dengan ketentuan syar'i. ${ }^{6}$

4. Menurut instruksi Presiden Nomor 1 Tahun 1991 tentang kompilasi hukum Islam pasal 171 huruf a dinyatakan bahwa; hukum kewarisan Islam adalah hukum yang mengatur tentang kepindahan hak pemilikan harta peninggalan (tirkah) pewaris, menentukan siapa-siapa yang berhak menjadi ahli waris dan berapa bagiannya masing-masing.

Berdasarkan berbagai defenisi diatas maka penyusun menyimpulkan bahwa yang dimaksud hukum kewarisan Islam adalah Kumpulan peraturan hukum tentang pembagian harta peninggalan dari seseorang yang telah meninggal dunia dan pengaturan pembagian masing-masing para ahli waris atas harta pusaka tersebut dan diladalamnya mengandung tiga unsur yang harus diperhatikan yaitu pewaris, ahli waris, dan harta yang ditinggalkan seseorang pewaris berdasarkan ketetapan Al-Qur'an dan Hadits.

${ }^{4}$ Idris Ramulyo, Hukum Kewarisan Islam: Studi Kasus, Perbandingan Ajaran Syafii (Patrilinial), Hazairin (Bilateral) dan Praktek di Pengadilan Agama, h. 49.

${ }^{5}$ Wiryono Projodikora, Hukum Warisan di Indonesia (Bandung: Sumur Bandung, 1966), h. 27

${ }^{6}$ Idris Jakfar dan Taufiq Yahya, Kompilasi Hukum Kewarisan Islam (Bandung: Diponegoro, 1995), h. 4 


\section{Dasar-dasar Hukum Kewarisan Islam}

\section{a. Al-Qur'an}

Hukum kewarisan Islam bersumber dari Al-Qur'an dan Sunnah Rasulullah baik secara tegas mengatur, maupun yang secara tersirat. Dalam hal ini dikemukakan beberapa ayat dan hadits yang berhubungan dengan Hukum Kewarisan Islam.

1. Surat An Nisa ayat 2

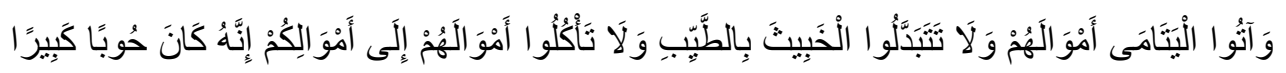

Terjemahan:

"Dan berikanlah kepada anak-anak yatim (yang sudah balig) harta mereka, jangan kamu menukar yang baik dengan yang buruk dan jangan kamu makan harta mereka bersama hartamu, Sesungguhnya tindakan-tindakan (menukar dan memakan) itu, adalah dosa yang besar."

Ayat diatas, Allah memerintahkan adar menyegerakan pelaksannan pembagian harta bagi anak yatim yang sudah dewasa dan Allah露 melalarang memakan harta anak yatim itu dengan mencampuradukkan dengan harta kita, sebab perbuatan yang demikian merupakan dosa besar.

2. Surat An Nisa ayat 7

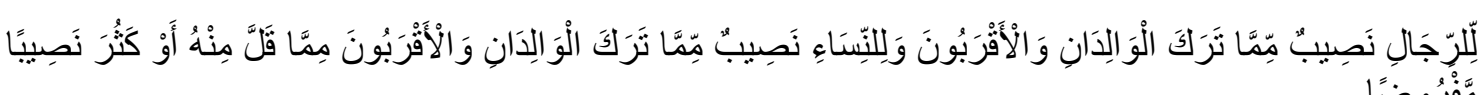

Terjemahan:

"Bagi orang laki-laki ada hak bagian dari harta peninggalan ibu-bapa dan kerabatnya, dan bagi orang wanita ada hak bagian (pula) dari harta peninggalan ibu-bapa dan kerabatnya, baik sedikit atau banyak menurut bahagian yang telah ditetapkan."

Ayat tersebut menyatakan bahwa laki-laki dan perempuan dapat mewaris dan selanjutnya baik laki-laki maupun perempuan akan memperoleh warisan dari kedua ibu/bapaknya dan kaum kerabatnya.

3. Surat An Nisa ayat 176

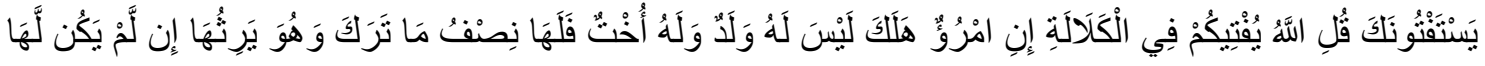

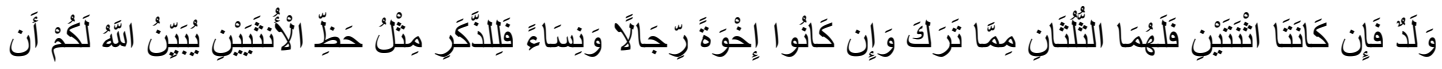

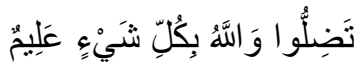

Terjemahan:

"Mereka meminta fatwa kepadamu (tentang kalalah). Katakanlah: "Allah memberi fatwa kepadamu tentang kalalah (yaitu): jika seorang meninggal dunia, dan ia tidak mempunyai anak dan mempunyai saudara perempuan, maka bagi saudaranya yang perempuan itu seperdua dari harta yang ditinggalkannya, dan 
saudaranya yang laki-laki mempusakai (seluruh harta saudara perempuan), jika ia tidak mempunyai anak; tetapi jika saudara perempuan itu dua orang, maka bagi keduanya dua pertiga dari harta yang ditinggalkan oleh yang meninggal. Dan jika mereka (ahli waris itu terdiri dari) saudara-saudara laki dan perempuan, maka bahagian seorang saudara laki-laki sebanyak bahagian dua orang saudara perempuan. Allah menerangkan (hukum ini) kepadamu, supaya kamu tidak sesat. Dan Allah Maha Mengetahui segala sesuatu."

Ayat diatas menerangkan tentang arti "kalalah" (yaitu); Jika seorang meninggal dunia, dan ia tidak mempunyai anak dan mempunyai saudara perempuan, maka bagi saudaranya yang perempuan itu seperdua dari harta yang ditinggalkannya, dan saudaranya yang laki-laki mempusakai (seluruh harta saudara perempuan) jika ia tidak mempunyai anak; tetapi jika saudara perempuan itu dua orang, maka bagi keduanya dua pertiga dari harta yang ditinggalkan oleh yang meninggal. Dan jika mereka (ahli waris itu terdiri atas) saudara-saudara laki-laki dan perempuan, maka bagian seorang saudara laki-laki sebanyak bagian dua orang saudara perempuan.

b. As-Sunnah

Menurut Ahmad Rofiq(2000:379) bahwa Imam Al Bukhari menghimpun hadits tentang Hukum Kewarisan Islam tidak kurang dari 46 hadits. Imam Muslim menyebut hadits-hadits kewarisan kurang lebih 20 hadits $^{7}$, misalnya :

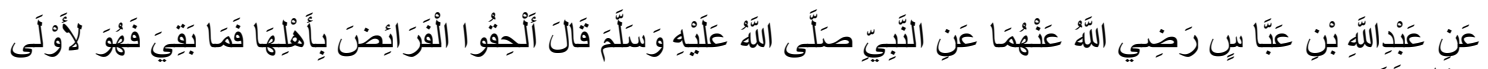

Terjemahan:

"Dari Abdullah bin Abbas Radhiyallahu 'anhuma, dari Nabi Shallallahu 'alaihi wa sallam, beliau bersabda, "Berikanlah warisan kepada orang yang berhak menerimanya, dan sisanya untuk orang-orang laki-laki yang paling berhak"

c. Ijma'

Yaitu kesepakatan para ulama atau sahabat sepeninggal Rasulullah tentang ketentuan warisan yang terdapat dalam Al-Qur'an dan dalam As-Sunnah. Oleh karena telah disepakati para sahabat Nabi dan ulama', ijma' dapat dijadikan sebgai sumber hukum.

d. Ijtihad

Ijtihad adalah pemikiran sahabat Nabi atau ulama dalam menyelesaikan kasuskasus pembagian warisan, yang belum atau tidak disepakati, misalnya masalah radd atau 'aul, di dalamnya terdapat perbedaan pendapat, sejalan dengan hasil ijtihad masing-masing sahabat, tabi'in atau ulama.

\section{Asas-asas Hukum Kewarisan Islam}

Berdasarkan ayat-ayat Al-Qur'an dan Hadits Rasulullah yang menjadi dasar Hukum Kewarisan Islam yang telah dikemukakan bahwa dalam Al-Qur'an dan Hadits

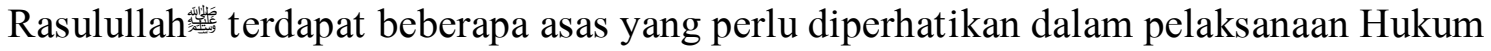
Kewarisan Islam.

${ }^{7}$ Ahmad Rofiq, Fiqih Mawaris, (Jakarta: PT. Raja Grafindo Persada, 200), h. 379 
Menurut Muhammad Daud Ali (1990 : 126-127) asas-asas dalam Hukum Kewarisan Islam yakni :

1. Asas Ijbari ; mengandung arti bahwa peralihan harta dari seseorang yang meninggal dunia kepada ahli warisnya menurut ketetapan Allah 䌙 tanpa digantungkan kepada kehendak pewaris atau ahli waris. Unsur kewajiban (ijbari) dalam Hukum Kewarisan Islam itu terutama terlihat dari segi ahli waris wajib menerima berpindahnya harta pewaris kepadanya sesuai dengan jumlah yang telah ditentukan oleh Allah糮.

2. Asas Bilateral ; maksudnya bahwa seseorang menerima hak warisan dari kedua belah pihak yaitu dari pihak kerabat keturunan laki-laki dan dari pihak kerabat keturunan perempuan.

3. Asas Individual ; maksudnya bahwa harta warisan dapat dibagi-bagi pada masing-masing ahli waris untuk dimiliki secara perorangan. Dalam hal ini setiap ahli waris berhak atas bagian yang didapatnya tanpa terikat pada bagian ahli waris yang lain, sebab bagian masing-masing sudah ditentukan.

4. Asas Kewajiban yang Berimbang; asas ini mengandung pengertian bahwa harus senantiasa terdapat keseimbangan antara hak dan kewajiban, antara hak yang diperoleh seseorang dengan kewajiban yang harus ditunaikan, laki-laki dan perempuan misalnya mendapat hak yang sebanding dengan kewajiban yang dipikulnya masing-masing kelak dalam kehidupan keluarga dan masyarakat. Dalam sistem kewarisan Islam, harta peninggalan yang diterima ahli waris oleh pewaris pada hakekatnya adalah kelanjutan tanggung jawab masing-masing terhadap keluarganya.

5. Asas Akibat Kematian ; Maksudnya bahwa kewarisan semata-mata sebagai akibat dari kematian seseorang. Peralihan harta seseorang kepada orang lain yang disebut kewarisan baru terjadi setelah orang meninggal dunia. Dengan demikian tidak ada harta kewarisan jika orang yang mempunyai harta masih hidup.

6. Asas Persunalitas Keislaman dipandang sebagai salah satu fundamental menegakkan eksistensi lingkungan peradilan agama, merupakan pelaksanaan dari penjelasan Pasal 10 Undang-Undang Nomor 14 Tahun 1970, yang menentukan bahwa salah satu dari ciri-ciri eksistensi kekhususan lingkungan peradilan agama, digantungkan kepada faktor golongan rakyat "tertentu" dan siapa rakyat golongan tertentu tersebut ialah yang dijawab Pasal 2, Jo Pasal 49 Ayat 1, Jo panjelasan umum angka 2 alinea ketiga Undang-Undang Nomor 7 Tahun 1989 yakni golongan rakyat yang bergama Islam ${ }^{8}$.

Selanjutnya Idris Jakfar dan Taufiq Yahya (1995:28) menerangkan asas keenam bahwa : asas ini menyatakan bahwa peralihan harta warisan hanya terjadi apabila diantara pewaris dan ahli waris sama-sama menganut agama Islam ${ }^{9}$. Logika yang dikemukakan dalam asas ini adalah bahwa persoalan kewarisan merupakan alat penghubung untuk mempertemukan ahli waris dengan pewaris disebabkan oleh adanya

\footnotetext{
${ }^{8}$ Muhammad Daud Ali. Asas-asas Hukum Islam (Pengantar Ilmu Hukum dan Tata Hukum Islam Indonesia) (Jakarta: Rajawali Pres, 1990), h. 126-127

${ }^{9}$ Idris Jakfar dan Taufiq Yahya, 1995 Kompilasi Hukum Kewarisan Islam (Bandung: Diponegoro), h. 28
} 
kekuasaan perwalian dan adanya jalinan rasa tolong-menolong diantara keduanya. Keenam asas Hukum Kewarisan Islam yang bersumber dari Al-Qur'an dan Sunnah Rasulullah merupakan landasan fundamental dalam melaksanakan Hukum Kewarisan Islam dalam wadah Negara Kesatuan Republik Indonesia.

\section{Cara Pembagian Warisan}

\section{Menentukan asal masalah/pokok masalah}

Dimaksud dengan asal masalah adalah sebagaimana istilah dalam ilmu matematika yang disebut Kelipatan Persekutuan Terkecil (KPT). (A. Assaad Yunus, $1992: 105)^{10}$.

Untuk memudahkan pembagian warisan dengan menggunakan angka pecahan, maka asal masalahnya (KPTnya) yang dicari lebih dahulu, yakni menyamakan angka penyebutnya. Dengan demikian, A. Assaad Yunus (1992 : 105-109) menjelaskan cara menentukan asal masalah/pokok masalah (KPT), harus dipahami istilah-istilah yang dipakai dalam ilmu faraid berikut ini ${ }^{11}$ :

a. Bast, yaitu angka at as pecahan yang disebut pembilang.

b. Makaam, yaitu angka bawah pada pecahan yang disebut penyebut.

c. Kasr, yaitu tiap-tiap suku bilangan yang memakai bast dan makaam seperti $1 / 2,1 / 3,2 / 3,3 / 4,4 / 5$ dan seterusnya.

d. Tamatsul, yaitu pecahan (Kasr) yang sama penyebutnya (Makaam nya), atau penyebut sama besarnya.

Contoh ahli waris terdiri dari A \& B. A mendapat $1 / 3$ dan B mendapat $2 / 3$, kasus ini angka penyebutnya sama besarnya yaitu 3 , jadi asal masalahnya harus ditetapkan 3. Maka pembagiannya adalah :

A mendapat $1 / 3=1 / 3 \times 3=1$

B mendapat $2 / 3=2 / 3 \times \underline{3=2}$

Jumlah $\quad=3 \quad$ (sesuai dengan asal masalah)

e. Tadakhul, yaitu dua angka yang berlebih kurang, tetapi angka besar bisa habis apabila digugurkan satu akali, dua kali, tiga kali dan seterusnya. Seperti : angka 2 dengan 4, 6, 8, 10, 12 dan seterusnya. Begitu pula angka 3 bisa masuk pada angka 6, 9, 12, 15 dan seterusnya. Dalam masalah faraid apabila ada angka yang tadakhul, maka angka yang kecil dianggap tidak ada, dan angka yang besar itulah yang menjadi asal masalah.

Contoh : ahli waris terdiri dari A, B, dan C. A mendapat 1/2, B mendapat 1/4, dan $\mathrm{C}$ mendapat ashabah. Pada kasus ini angka 2 bisa masuk ke angka 4, maka angka 2 dianggap tidak ada, dan asal masalah harus ditetapkan 4. Jadi pembagiannya adalah :
A mendapat $1 / 2$
$=1 / 2 \times 4=2$
B mendapat $1 / 4$
$=1 / 4 \times 4=1$
C mendapat sisa (ashabah)
$=4-(2+1)=1$
Jumlah
$=4$ (sesuai dengan asal masalah)

\footnotetext{
${ }^{10}$ A. Assaad Yunus, Hukum Kewarisan Islam (Al-Quswa, 1992), h. 105

${ }^{11}$ A. Assaad Yunus, Hukum Kewarisan Islam, h. 105-109
} 
f. Tabayun, yakni dua angka yang berlebih kurang, tetapi kedua-duanya tidak bisa dihabisi melainkan hanya angka 1, seperti : 1/3 dengan 1/4. Angka tersebut, keduanya tidak bisa habis dengan menggugurkan dua, oleh karena angka 3 itu jika digugurkan 2, maka tinggal 1. Jadi angka 2 tidak bisa menghabiskan angka 3, tetapi bisa menghabiskan angka 4. Dengan demikian itu, jika bertemu tabayun didalam pelaksanaan pembagian harta warisan, untuk mencari asal masalahnya (KPTnya), maka angka penyebutnya dikalikan yaitu $3 \times 4=12$ jadi asal masalahnya (KPTnya) adalah 12.

g. Tawaffiq, yakni dua angka yang berlebih kurang. Seperti : 1/4 dengan $1 / 6$, dan $1 / 8$. Dalam hal ini, jjika bertemu dengan angka tawafuq, maka untuk mencari asal masalahnya (KPTnya) atau menyamakan penyebutnya, maka dikalikan penyebutnya kemudian dikalikan dengan $1 / 2$.

Contoh : ahli waris terdiri dari A, B, dan C. A mendapat 1/4, B mendapat 1/6, dan $\mathrm{C}$ mendapat sisa (ashabah), maka asal masalahnya (KPTnya) yaitu $=4 \mathrm{x}$ $6 \times 1 / 2=12$, jadi adal masalahnya 12. Pembagiannya adalah :
A mendapat $1 / 4$
$=1 / 4 \times 12=3$
B mendapat $1 / 6$
$=1 / 6 \times 12=2$
C mendapat sisa (ashabah) $=12-(3+2)=7$
Jumlah
masalahnya) ${ }^{12}$
(sesuai dengan asal

\section{Analisis Faktor-Faktor Berpengaruh Terhadap Pelaksanaan Hukum Kewarisan Islam Di Kota Makassar}

Analisis pendekatan normatif terhadap faktor substansi hukum.

a. Inventarisasi Hukum

- Undang-undang Nomor 7 Tahun 1989 tentang peradilan agama.

- Instruksi Presiden R.I. Nomor 1 Tahun 1991 tentang penyebarluasan Kompilasi Hukum Islam.

- Keputusan Menteri Agama R.I. Nomor 154 Tahun 1991 tentang pelaksanaan Instruksi Presiden R.I. Nomor 1 Tahun 1991 Tanggal 10 Juni 1991 tentang Kompilasi Hukum Islam.

- Surat Edaran Direktur Pembinaan Badan Peradilan Agama Islam Nomor 3694/E.V/HK.03.4/AZ/1991 tanggal 25 Juli 1991.

Berdasarkan peraturan perundang-undangan yang mengatur Hukum Kewarisan Islam tersebut, bila di analisis maka hal tersebut menunjukkan bahwa peraturan perundangan secara hirarki pemberlakuan Kompilasi Hukum Islam (vide buku II tentang Hukum Kewarisan Islam) baru berbentuk Instruksi Presiden yang isinya bersifat anjuran untuk menyebarluaskan Kompilasi Hukum Islam agar digunakan oleh instansi pemerintah dan masyarakat yang memerlukannya.

b. Sinkronisasi Hukum

Berdasarkan analisis isi ketentuan Undang-Undang Nomor 7 Tahun 1989 mengenai kewenangan Pengadilan Agama untuk melaksanakan Hukum Kewarisan Islam yang tertuang dalam Kompilasi Hukum Islam, tampak adanya ketimpangan

\footnotetext{
${ }^{12}$ A. Assaad Yunus, Hukum Kewarisan Islam.
} 
antara masalah kompetensi dan pilihan hukum (choice of law) dalam perkara kewarisan.

Ketimpangan itu terjadi dalam Penjelasan Umum butir 2 Undang-Undang Nomor 7 Tahun 1989 yang dinyatakan dibidang kewarisan adalah mengenai penentuan siapa-siapa yang menjadi ahli waris, penentuan bagian masing-masing ahli waris, dan pelaksana pembagian harta peninggalan tersebut, jika pewarisan tersebut dilaksanakan berdasarkan hukum Islam.

Hal tersebut memberikan pertimbangan kepada para pihak untuk memilih hukum apa yang akan digunakan dalam pembagian warisan, yakni apakah hukum Islam, hukum adat atau hukum perdata(BW), apabila ahli waris sepakat untuk memilih hukum waris Islam tidak ada masalah, begitu pula sebaliknya jika ahli waris sepakat untuk memilih jalur lewat hukum perdata juga tidak bermasalah, namun yang menjadi persoalan jika salah satu ahli waris memilih hukum perdata dan yang satu memilih hukum Islam atau hukum adat, disinilah timbul persoalan. Seharusnya bagi yang beragama Islam harus memilih hukum Islam yang menjadi pilihan dalam menyelesaikan persoalan kewarisan dan jika ini dilakukan maka PN tidak mematuhi Surat Edaran Mahkamah Agung Nomor 2 Tahun 1990, tanggal 3 April 1990, dari apa yang telah tertuang dalam penjelasan umum sub 2 alinea keempat tidak sinkron dengan bab III pasal 49 ayat (1) dan (3) Undang-undang no 7 tahun 1989. Meskipun demikian dari uraian tugas dan kewenangan Pengadilan Agama sebagaimana yang terdapat dalam pasal 49 ayat (1) dan (3) Undang-undang Nomor 7 Tahun 1989 sudah jelas.

2. Analisis pendekatan sosiologis terhadap faktor-faktor sosial.

a. Tingkat pengetahuan masyarakat.

Menurut Kurchinsky dalam buku Teori Hukum karangan Rusli Efendy Dkk menjelaskan bahwa ada 4 faktor yang sangat erat kaitannya dengan kepatuhan masyarakat terhadap hukum yakni : (1) pengetahuan tentang peraturan, (2) pengetahuan tentang isi peraturan, (3) sikap tehadap kaidah hukum tertentu dan (4) perilaku hukum ${ }^{13}$.

b. Tingkat pengetahuan aparat terkait.

Tingkat pengetahuan aparat terkait dianggap cukup mengetahui tentang Hukum Kewarisan Islam jadi dalam hal ini tingkata pengetahuan aparat tentang masalah kewarisan tidak ada masalah, meskipun demikian masih sangat perlu menambah wawasan dan pengetahuan tentang Hukum Kewarisan Islam.

c. Tingkat persepsi masyarakat.

Tingkat masyarakat adalah tanggapan (penerimaan) langsung masyarakat yang dapat dilihat dari sikap masyarakat mengenai Hukum Kewarisan Islam yang telah diatur dalam Kompilasi Hukum Islam. Jadi dalam hal ini tingkat implementasi masyarakat dalam hal pembagian kewarisan masih sangat berpariasi, tergantung dari kondisi mana yang masyarakat butuhkan, tergantung dari kesepakatan masing-masing yang bersangkutan, apakah itu mereka memilih pembagianya menurut hukum Islam, atau apakah mereka memilih Hukum Adat, maupun hukum perdata.

\footnotetext{
${ }^{13}$ Rusli Efendi dkk, Teori Hukum (Ujung Pandang: Hasanuddin University Pres, 1991), h. 77
} 
Dengan demikian pelaksanaan hukum Kewarisan Islam dikota makassar sangat belum evektif berjalan, sehingga dalam hal ini sangat dibutuhkan ketegasan dari pemerintah, tokoh agama, tokoh masyarakat Islam untuk senantiasa mensosialisasikan kepada masyarakat agar dapat mengamalkan ajaran Islam ini ditengah-tengan masyarakat, terutama tentang pelaksanaan hukum kewarisan Islam di kota makassar.

\section{PENUTUP}

\section{Kesimpulan}

Dari pembahasan yang telah dikemukakan di atas, maka dapat diambil kesimpulan sebagai berikut :

1. Pelaksanaan Hukum Kewarisan Islam di Kota Makassar belum berjalan.

2. Pelaksanaan Hukum Kewarisan Islam di Kota Makassar belum berjalan dipengaruhi 6 faktor, yakni :
a. Substansi Hukum
b. Tingkat pengetahuan masyarakat
c. Tingkat pengetahuan aparat
d. Tingkat persepsi masyarakat
e. Tingkat kebiasaan (budaya hukum) masyarakat
f. Tingkat kesadaran hukum masyarakat

\section{Implikasi}

1. Perlu adanya upaya yang maksimal dari pemerintah di Kota Makassar, untuk lebih mensosialisasikan Hukum Kewarisan Islam, dengan merangkul para ulama, ormas Islam, tokoh masyarakat dalam rangka meningkatkan pengetahuan hukum masyarakat.

2. Hukum Kewarisan Islam yang erat kaitannya dengan syari'at agama Islam, maka :

a. Diharapkan kepada pihak yang berwenang agar dalam membuat atau melahirkan suatu aturan tentang Hukum Kewarisan Islam yang lebih konkrit, tegas dan jelas sehingga jelas kewenangan dalam mengadili.

b. Dalam rangka meningkatkan pengetahuan masyarakat terhadap Hukum Kewarisan Islam, perlu diadakan penyuluhan hukum secara intensif

c. Untuk meningkatkan pengetahuan aparat terkait terhadap Hukum Kewarisan Islam, perlu diadakan penyuluhan tentang Kompilasi hukum Islam.

d. Untuk meluruskan persepsi masyarakat terhadap Hukum Kewarisan Islam perlu adanya penyuluhan hukum tentang Hukum Kewarisan Islam.

e. Untuk meluruskan budaya hukum masyarakat terhadap Hukum Kewarisan Islam perlu adanya penyuluhan hukum tentang Hukum Kewarisan Islam Hukum.

f. Untuk terlaksananya Hukum Kewarisan Islam Khususnya buku II tentang kewarisan ditingkatkan menjadi suatu Undang Undang. 


\section{DAFTAR PUSTAKA}

Ali, Muhammad Daud. Asas-asas Hukum Islam (Pengantar Ilmu Hukum dan Tata Hukum Islam Indonesia). Jakarta: Rajawali Pres, 1990.

Departemen Agama RI. Al-Qur'an dan Terjemahannya. Semarang: CV. Toha Putra, 1989.

Projodikora, Wiryono. Hukum Warisan di Indonesia. Bandung: Sumur Bandung, 1966.

Ramulyo, Idris. Hukum Kewarisan Islam: Studi Kasus, Perbandingan Ajaran Syafii (Patrilinial), Hazairin (Bilateral) dan Praktek di Pengadilan Agama. Cet. II; Jakarta: Indhil. 1987.

Rofiq, Ahmad. Fiqih Mawaris. Jakarta: PT. Raja Grafindo Persada, 2002

Rusli Efendi, Achmad Ali, dan Poppy Andilolo. Teori Hukum. Ujung Pandang: Hasanuddin University Pres,. 1991

Sudarsono. Hukum Waris dan Sistem Bilateral. Jakarta: Rineka Cipta, 1991

Yahya, Idris Jakfar dan Taufiq. Kompilasi Hukum Kewarisan Islam, Bandung: Diponegoro. 1995

Yunus, A. Assaad. Hukum Kewarisan Islam. Jakarta: Al-Quswa, 1992 